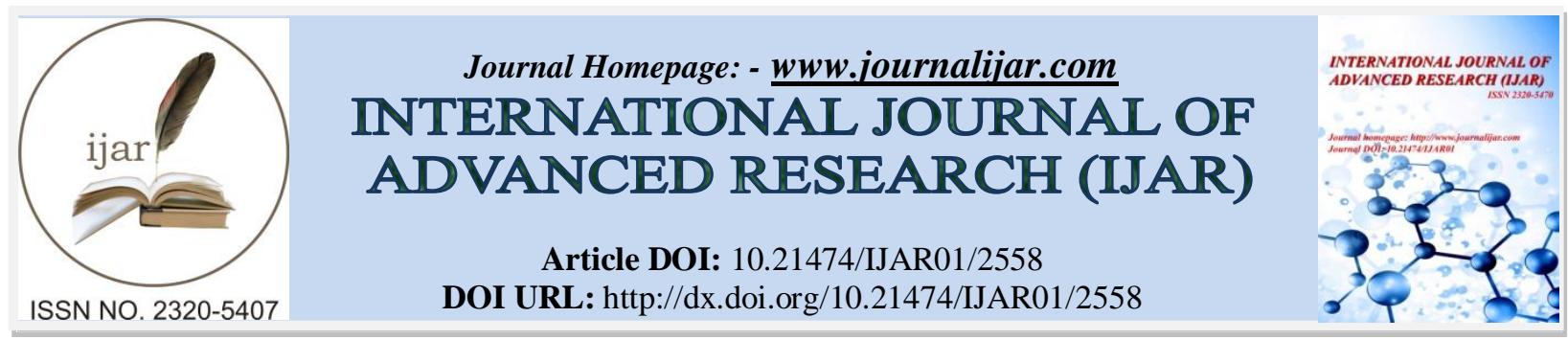

RESEARCH ARTICLE

\title{
STUDIES ON PHYTOPLANKTON DIVERSITY AND WATER QUALITY ASSESSMENT OF A POND WATER IN SIRUKALATHUR PANCHAYAT, KUNDRATHUR TOWN PANCHAYAT, KANCHIPURAM DISTRICT, TAMIL NADU, INDIA.
}

"Shobana $\mathbf{R}^{1}$ and Soruba $\mathbf{R}^{2}$.

1. Department of Science and Humanities, Jeppiaar Maamallan Engineering College, Sriperumpudur-5, Tamil Nadu, India.

2. Department of Biotechnology, Quaid- E-Millath Government College for Women, Chennai-2, Tamil Nadu, India.

\section{Manuscript Info}

Manuscript History

Received: 27 October 2016

Final Accepted: 25 November 2016

Published: December 2016

Key words:-

Surface water, Sirukalathur, Pond, Physical-Chemical quality, Biological parameter.

\section{Abstract}

A study on the water quality of a pond water in Sirukalathur panchayat, Kundrathur town panchayats, Kanchipuram District To assess the extent of water pollution for the domestic purposes. A pond water in Sirikalathur panchayat is located at $14^{\circ} 16^{\prime} 00^{\prime} \mathrm{N}$ $70^{\circ} 16^{\prime} 00^{\prime} \mathrm{E} 13^{\circ} 97^{\prime} 00^{\prime} \mathrm{N} 80^{\circ} 37^{\prime} 00^{\prime} \mathrm{E}$. The samples of pond water were collected for about Nine Month November 2009 to July 2010. The samples were analysed using standard methods of APHA (1995) and BIS (1991) the results of Physical-Chemical parameters and biological parameters were analyzed. It showed that the samples were highly turbid and the results showed the samples were highly alkaline. Total of 51 species were identified. The characteristic and availability of water had been greatly affected due to population, indiscriminate usage and disposal of water. It is concluded that the Biological and Physical-Chemical parameters were discussed.

Copy Right, IJAR, 2016,. All rights reserved.

\section{Introduction:-}

Phytoplankton is the basic food chain component of the aquatic ecosystem. They are distributed in both fresh and marine water ecosystem. They are predominant in fresh water (Ariyadej.C., 2004). A study of Phytoplankton community structure is an indirect assessment of water quality and pollution. Over growth of Phytoplankton lead to algal bloom in aquatic ecosystem, It plays the significant role in degrading the organic matter (Adesalu and Navanko 2008). Phytoplankton is the detectors of environmental changes and other chemicals (Kishore and Joshi 2002). Now-a-days due to sewage and other human activities, the degree of pollution increases, which minimize the number of algal species, but increases the number of individual tolerant species. Pollution brings changes in water quality, modifies the biotic component and elimination of the valuable species. The blue-green algae produce toxins leads to affect the fish growth and some phytoplankton, produce intolerable odor. Many researchers have reported phytoplankton plays the significant role in determining the phyto-algal biodiversity and serves as an index of extent of water pollution. In this study the water quality parameters and biological parameters of Sirukalathur pond water for a period of November 2009 to July 2010 were assessed.

Corresponding Author:- Shobana R.

Address:- Department of Science and Humanities, Jeppiaar Maamallan Engineering College, 


\section{Materials And Methods:-}

The water sample and Phytoplankton samples were collected from the pond water in Sirukalathur panchayat, Kundrathur town panchayat, Kanchipuram District (Map -1) Sirikalathur panchayat is located at $14^{\circ} 16^{\prime} 00^{\prime \prime} \mathrm{N}$ $70^{\circ} 16^{\prime} 00^{\prime \prime} \mathrm{E} 13^{\circ} 97^{\prime} 00^{\prime} \mathrm{N} 80^{\circ} 37^{\prime} 00^{\prime \prime} \mathrm{E}$. The size of the pond is five hundred feet in length, three hundred feet in width and twenty two feet in depth. The samples of pond water were collected for about Nine Month from November 2009 to July 2010 in two litres polythene canes. Plankton net ( 200 mesh/linear inch) was used for the collection and the samples were mixed with $4 \%$ formalin. At the time of collection of water samples the air and water temperature $\left({ }^{\circ} \mathrm{C}\right)$ were recorded. The Physical-Chemical parameters of the samples were analysed using standard methods of APHA (1995) Trivedy and Goel (1986) and BIS (1991) and presented in the tabular and graphical form Venkateswaralu (2006), the phytoplankton were analyzed for the identification under the microscope. The studies were carried out as such as (Fritsch 1935, 1945). Desikatchary (1959), Philipose (1967), Prescott (1969), Iyengarand Desikachary (1981), Krishnamoorthy (2000), Rath and Adhikary (2005).

\section{MAP SHOWING THE LOCATION OF STUDY SITE}

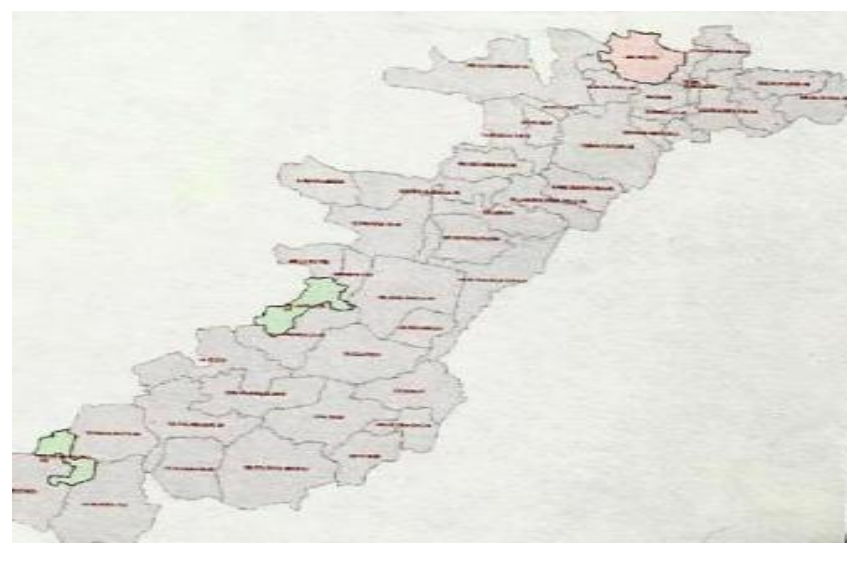

Figure-1:- Kundrathur town panchayat

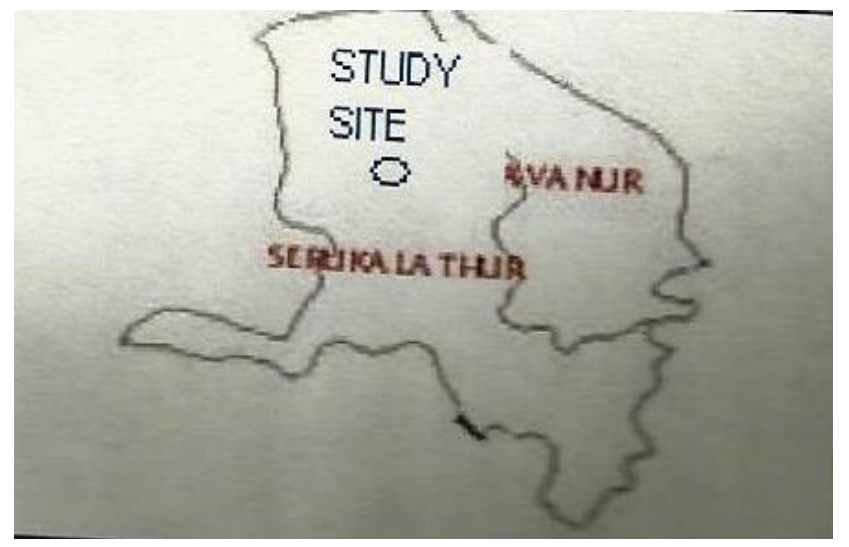

Figure-2:- Sirukalathur Study Site

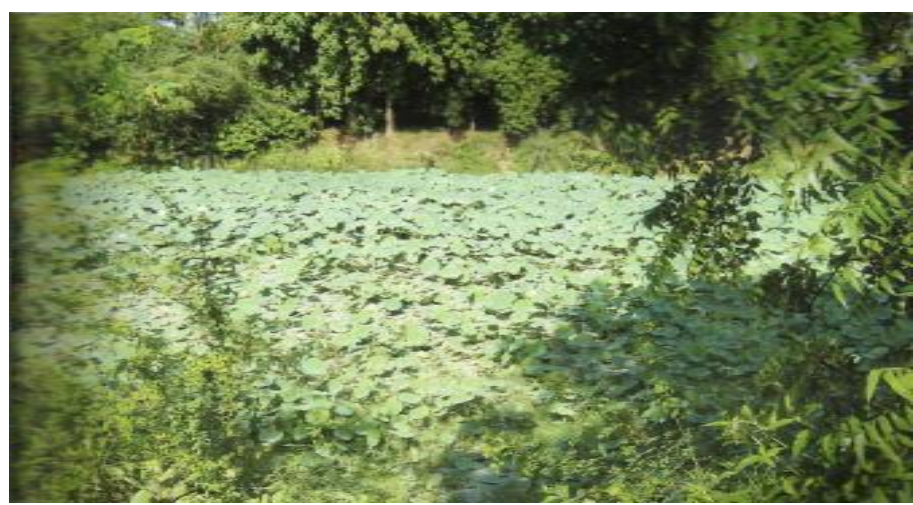

Figure-3:- Sirukalathur Pond

\section{Results:-}

The present investigation was carried out in a pond at Sirukalathur,Kundrathur town panchayat, Kancheepuram District, Tamil Nadu, India. For a period of nine months from November 2009 to July 2010. The pond water Air temperature ranged between $29^{\circ} \mathrm{C}$ and $36^{\circ} \mathrm{C}$ and water temperature ranged from $25^{\circ} \mathrm{C}$ and $33.5^{\circ} \mathrm{C}$. Turbidity and Total dissolved solid levels found from 0.1 to 15.9 NTU, high turbid range was observed in the month of January 10 and low in February 10. Total dissolved solid levels found from 52 to $420 \mathrm{mg} / \mathrm{L}$ high range recorded in December09 and low in November-09. The chemical parameters: $\mathrm{pH}$ varied between 5.72 to $7.74 \mathrm{High} \mathrm{pH}$ values was recorded in December 09 and dissolved oxygen ranged from 0.9 to $2.6 \mathrm{mg} / \mathrm{L}$. Calcium, Magnesium, was less than the desirable limit. Nitrate, Chloride, Sulphate, Fluoride values were below the desired limit.Iron content recorded 
value was very low of $.07 \mathrm{mg} / \mathrm{L}$ and ranged high of $4.87 \mathrm{mg} / \mathrm{L}$ in the month of June 10. Silicate content varied between $1.89 \mathrm{mg} / \mathrm{L}$ and $12.99 \mathrm{mg} / \mathrm{L}$. The high value in February 10 and low in November 09 .

Physico-Chemical Parameters Of Sirukalathur Pond Water:

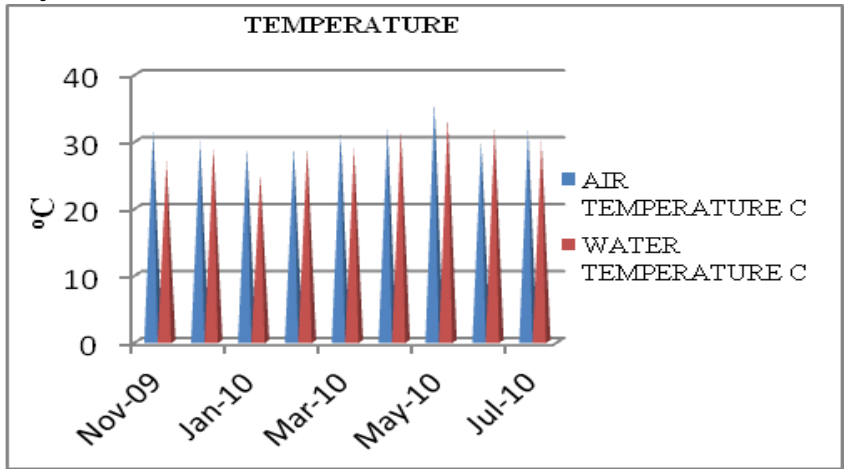

Figure-1, Temperature

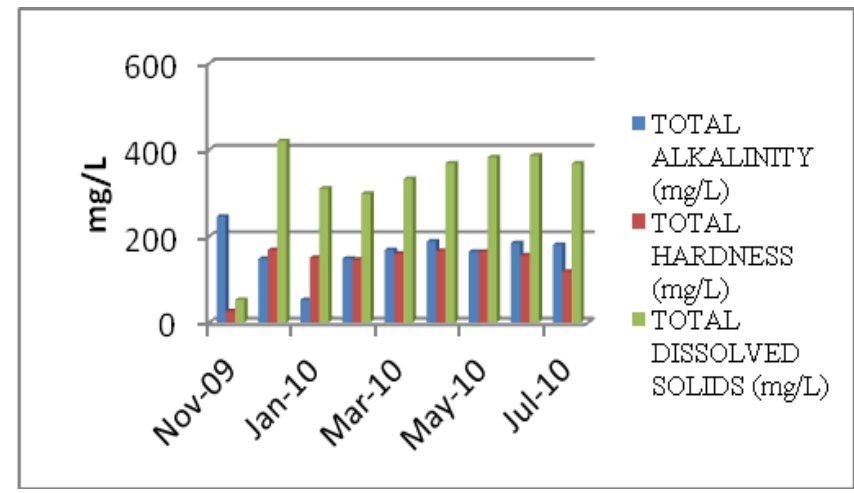

Figure-3:- Total Alkalinity, hardness,

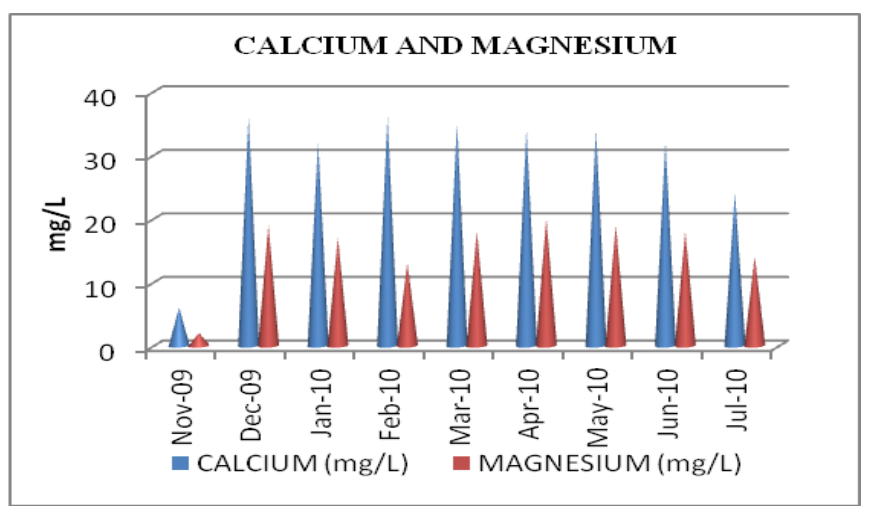

Figure-5, Calcium and Magnesium

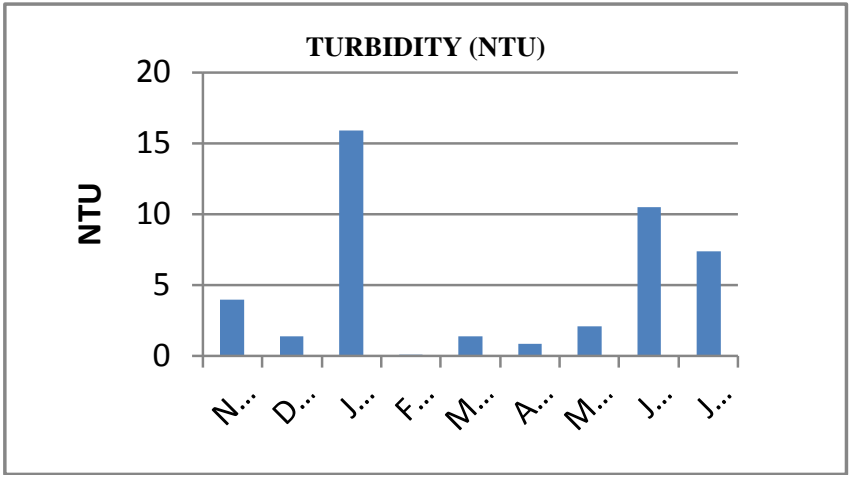

Figure-2, Turbidity (NTU)

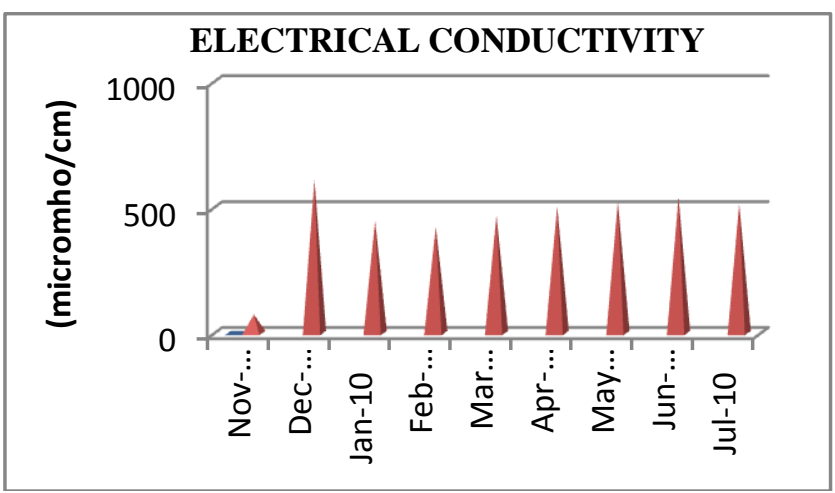

Figure-4:- Electrical Conductivity

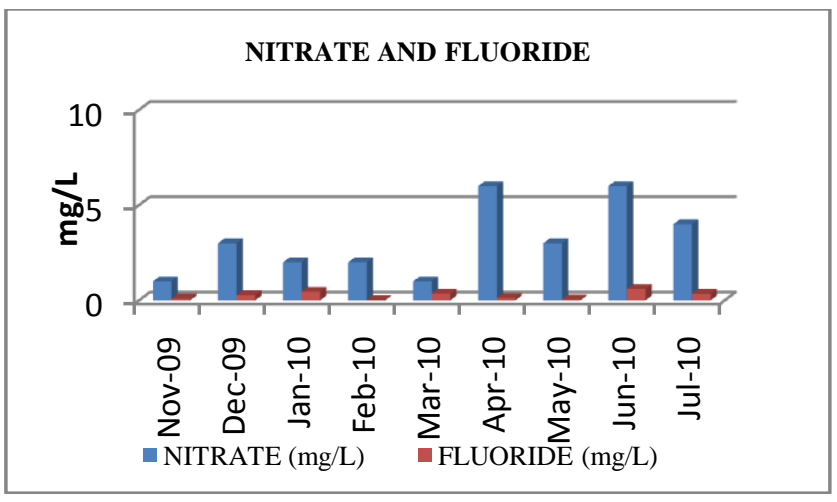

Figure-6, Nitrate and Fluoride 


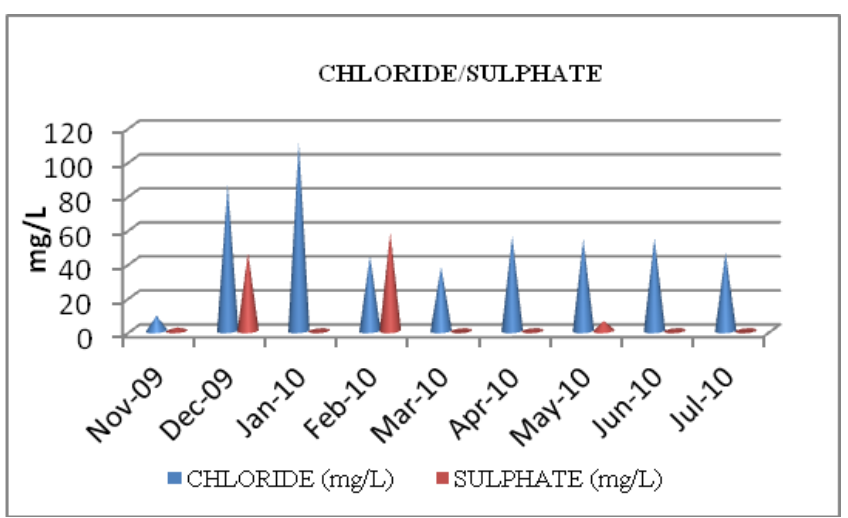

Figure-7:- Chloride and Sulphate

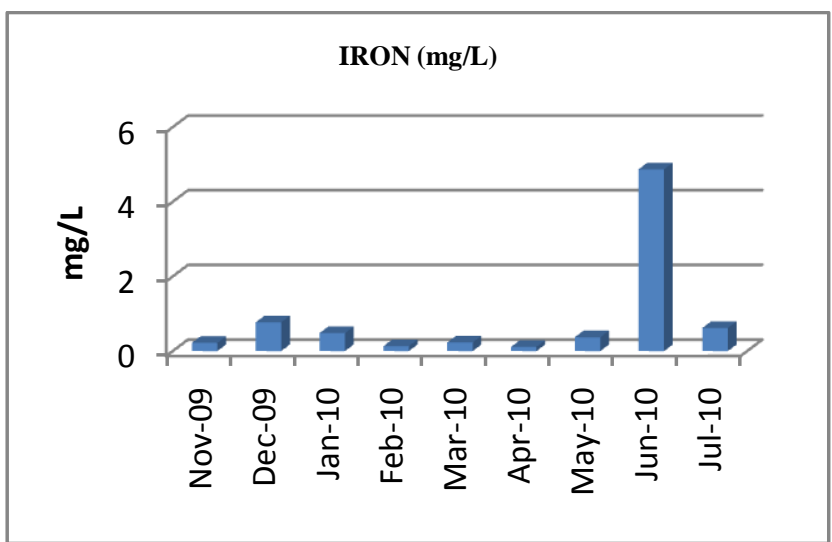

Figure-8:- Iron (mg/L)

Monthly variation of phytoplankton diversity during the period of november 2009 to july 2010:-

The numbers of phytoplankton were identified for every month throughout the study period. There are 54 species investigated in the period of study, the following species vary in each month. There are,

Table: 1

\begin{tabular}{|l|r|r|r|r|r|r|r|r|}
\hline PHYTOPLANKTONS & Nov- & Dec- & Jan- & Feb- & Mar- & Apr- \\
10 & 09 & 09 & 10 & $\begin{array}{r}\text { May- } \\
10\end{array}$ & $\begin{array}{r}\text { Jun- } \\
10\end{array}$ & $\begin{array}{r}\text { Jul- } \\
10\end{array}$ \\
\hline CYANOPHYCEAE & 8 & 3 & 4 & 3 & 10 & 3 & 2 & 5 \\
\hline CHLOROPHYCEAE & 8 & 8 & 2 & 4 & 5 & 2 & 2 \\
\hline BACCILLARIOPHYCEAE & 3 & 2 & & 6 & 3 & & & 2 \\
\hline EUGLENOPHYCEAE & 1 & & & 1 & 1 & & & 1 \\
\hline TOTAL & 20 & 13 & 6 & 14 & 19 & 3 & 2 & 8 \\
\hline
\end{tabular}

Table: 2

\begin{tabular}{|c|c|c|c|c|c|c|c|c|c|}
\hline PHYTOPLANKTONS & $\begin{array}{r}\text { Nov- } \\
09\end{array}$ & $\begin{array}{r}\text { Dec- } \\
09\end{array}$ & $\begin{array}{r}\text { Jan- } \\
10\end{array}$ & $\begin{array}{r}\text { Feb- } \\
10\end{array}$ & $\begin{array}{r}\text { Mar- } \\
10\end{array}$ & $\begin{array}{r}\text { Apr- } \\
10\end{array}$ & $\begin{array}{r}\text { May- } \\
10\end{array}$ & $\begin{array}{r}\text { Jun- } \\
10\end{array}$ & $\begin{array}{r}\text { Jul- } \\
10\end{array}$ \\
\hline CLASS-CYANOPHYCEAE & - & - & - & + & - & - & - & - & - \\
\hline $\begin{array}{l}\text { 1.Oscillatoria princepsmvaucher } \\
\text { (orig) }\end{array}$ & - & - & - & - & + & - & - & - & - \\
\hline 2.Oscillatoria tenuls (Ag) Ex.Gomt & - & + & + & - & - & - & - & + & + \\
\hline 3.Oscillatoria perronata skuja & + & - & - & - & + & - & - & + & - \\
\hline $\begin{array}{l}\text { 4.Oscillatoria cortiyana Meneghiniex } \\
\text { Gom }\end{array}$ & - & - & - & - & + & - & - & + & - \\
\hline 5.Phormidium rettali(Ag) Gom & - & - & + & + & + & - & - & - & - \\
\hline 6.Spirulina giganten Schemidle & - & - & - & + & + & - & - & - & - \\
\hline 7.Lyngybya porphyrosis Fremy & - & - & - & - & + & - & - & - & - \\
\hline 8.Anabaeba orientals Dixit & - & - & - & - & + & + & + & - & - \\
\hline 9.Anabaeba cylinrica Lemm & + & - & - & - & + & - & - & - & - \\
\hline 10..Anabaeba ambigua Rao:C.B. & - & - & - & - & + & + & + & - & - \\
\hline $\begin{array}{l}\text { 11. Camphylonemopsis lyegari } \\
\text { Desikachary }\end{array}$ & - & - & - & + & - & - & - & - & - \\
\hline 12.Westllopsis prolifiga janet & - & - & - & - & + & - & - & + & - \\
\hline 13. Gleotrachia ghosei Singh R.N. & - & - & - & - & - & - & - & + & + \\
\hline 14. Spharrozosma wallichi lacobs. & - & - & - & + & - & - & - & - & - \\
\hline
\end{tabular}


Table: 3

\begin{tabular}{|c|c|c|c|c|c|c|c|c|c|}
\hline PHYTOPLANKTONS & $\begin{array}{r}\text { Nov- } \\
09 \\
\end{array}$ & $\begin{array}{r}\text { Dec- } \\
09 \\
\end{array}$ & $\begin{array}{r}\text { Jan- } \\
10 \\
\end{array}$ & $\begin{array}{r}\text { Feb- } \\
10 \\
\end{array}$ & $\begin{array}{r}\text { Mar- } \\
10 \\
\end{array}$ & $\begin{array}{r}\text { Apr- } \\
10 \\
\end{array}$ & $\begin{array}{r}\text { May- } \\
10 \\
\end{array}$ & $\begin{array}{r}\text { Jun- } \\
10 \\
\end{array}$ & $\begin{array}{r}\text { Jul- } \\
10 \\
\end{array}$ \\
\hline \multicolumn{10}{|l|}{ CLASS-CHLOROPHYCEAE } \\
\hline 15. Pediastrum ovtum(ovate) & + & - & - & - & - & - & - & - & - \\
\hline $\begin{array}{l}\text { 16. Scenedesmus bijuga Var, irregular } \\
\text { (Wille) }\end{array}$ & - & - & - & + & + & - & - & - & - \\
\hline $\begin{array}{l}\text { 17. Scenedesmus Meyan Varflexious } \\
\text { (lemm) }\end{array}$ & - & - & - & + & - & - & - & - & - \\
\hline 18. Scenedesmus bernadi G.M. & - & - & - & + & + & - & - & - & - \\
\hline $\begin{array}{l}\text { 19.Scenedesmus incrassatulus Bohin } \\
\text { irregula }\end{array}$ & - & - & - & - & - & - & - & - & - \\
\hline 20.Scenedesmusoblique (Turp) Kurtz & - & - & - & - & + & - & - & - & - \\
\hline $\begin{array}{l}\text { 21.Clostridum siamensis(W.et G.S. } \\
\text { Wesr) }\end{array}$ & - & - & - & - & - & - & - & + & + \\
\hline 22.Clostridum sp.Reinsch & - & - & - & - & + & - & - & - & - \\
\hline 23.Clostridum ehsenbergi Menegh & - & - & - & - & - & - & - & - & - \\
\hline 24. Tetraedron bifidum(Turner)Wille & - & - & - & - & + & - & - & - & - \\
\hline $\begin{array}{l}\text { 25. Chlorochitrium } \\
\text { limnanthemum(Cunningh) }\end{array}$ & - & - & - & - & + & - & + & + & + \\
\hline 26. Chroccous turgidus Nag, & + & + & + & + & + & + & + & + & + \\
\hline $\begin{array}{l}\text { 27. Ankistrodesmus } \\
\text { convolutus(Corda) }\end{array}$ & + & - & - & - & - & - & - & - & - \\
\hline $\begin{array}{l}\text { 28. Ankistrodesmus falcatus } \\
\text { (Corda)Ralfs }\end{array}$ & + & - & - & - & - & - & - & - & - \\
\hline 29.Eremophaera virids (Debray) & + & - & - & - & - & - & - & - & - \\
\hline 30.Spirogyra grantiana Transeau & + & + & - & - & - & - & - & - & - \\
\hline 31.Chalamydomonas carteria Iyengari & + & + & - & - & - & - & - & - & - \\
\hline 32. Cladophora glamerata (L) Kutz & + & + & - & - & - & - & - & - & - \\
\hline 33.Gonatozygon brebissori Debray & - & - & + & - & - & - & - & - & - \\
\hline $\begin{array}{l}\text { 34.Gonatozygon Monotarniumi } \\
\text { Debray }\end{array}$ & + & + & - & - & - & - & - & - & - \\
\hline $\begin{array}{l}\text { 35. Cosmerium } \\
\text { pseudocaronatum,Turner }\end{array}$ & - & + & - & + & + & - & - & - & - \\
\hline
\end{tabular}

Table: 4

\begin{tabular}{|c|c|c|c|c|c|c|c|c|c|}
\hline PHYTOPLANKTONS & $\begin{array}{r}\text { Nov- } \\
09 \\
\end{array}$ & $\begin{array}{r}\text { Dec- } \\
09 \\
\end{array}$ & $\begin{array}{r}\text { Jan- } \\
10 \\
\end{array}$ & $\begin{array}{r}\text { Feb- } \\
10 \\
\end{array}$ & $\begin{array}{r}\text { Mar- } \\
10 \\
\end{array}$ & $\begin{array}{r}\text { Apr- } \\
10 \\
\end{array}$ & $\begin{array}{r}\text { May- } \\
10 \\
\end{array}$ & $\begin{array}{r}\text { Jun- } \\
10 \\
\end{array}$ & $\begin{array}{r}\text { Jul- } \\
10 \\
\end{array}$ \\
\hline \multicolumn{10}{|l|}{$\begin{array}{l}\text { CLASS- } \\
\text { BACILLARIOPHYCEAE }\end{array}$} \\
\hline 36. Mesotaenium sp., & - & - & - & - & - & - & - & + & + \\
\hline 37.Netrium digitus Her & - & - & - & - & + & - & - & - & - \\
\hline 38.Cymbelia calidrimaum Kurtz & + & - & - & - & - & - & - & - & - \\
\hline $\begin{array}{l}\text { 39.Licmophora abreviata } \\
\text { Agardh }\end{array}$ & + & + & - & - & - & - & - & - & - \\
\hline 40.Navicula papula Kurtz & + & + & - & - & - & - & - & - & - \\
\hline 41.Navicula subrhyncocephale & - & - & - & + & + & - & - & - & - \\
\hline 42.Navicula mutica & + & - & - & - & - & - & - & - & - \\
\hline 43. Mastogolia smithi thw & - & - & - & + & - & - & - & - & - \\
\hline 44.Melostria $\mathrm{sp}($ Her) Ralfs & - & - & - & - & + & - & - & - & - \\
\hline $\begin{array}{l}\text { 45. Cyclotella combta Var, } \\
\text { affins }\end{array}$ & + & - & - & - & - & - & - & - & - \\
\hline 46.Hypoglossum wood Ward & + & + & - & - & - & - & - & - & - \\
\hline 47. Pinnularia viridis (girdle & + & + & - & - & - & - & - & - & - \\
\hline
\end{tabular}




\begin{tabular}{|l|l|l|l|l|l|l|l|l|l|}
\hline view) & & & & & & & & & \\
\hline $\begin{array}{l}\text { CLASS- } \\
\text { BACILLARIOPHYCEAE }\end{array}$ & & & & & & & & & \\
\hline 48.Euglena gracilis Klebs & - & - & - & - & - & - & - & - & + \\
\hline 49.Phacus curvicauda Sersenko & + & - & - & - & - & - & - & - & - \\
\hline 50.Euglena proxima & - & - & - & - & - & + & - & - & - \\
\hline 51.Euglena mucifera Maink & - & - & - & + & - & - & - & - & - \\
\hline
\end{tabular}

\section{Discussion:-}

The pond water present the unique fresh water ecosystem. The composition of phytoplankton diversity serves as an important tool to analyze the water quality. Temperature variation of air and water reported in the study, which agreed with the study of Ariyadej et al., (2004), Rajagopal et al.,(2010) reported that the temperature plays in the growth of phytoplankton. The turbidity of the pond water was observed high in Jan10(15.9 NTU)-Turbidity is caused due to a side variety level of suspended solids, organic colloid compounds and coarse dispersion of sewage (AkbayNet.al., 1999 ,Kamat 2000)The total dissolved solids in the study ranged between $52 \mathrm{mg} / \mathrm{L}$ and $420 \mathrm{mg} / \mathrm{L}$. BIS(1994) recommends that the fish culture can be done when the total dissolved solid do not exceeds $400 \mathrm{mg} / \mathrm{L}$.. The $\mathrm{pH}$ value was from 5.72 to $7.74 \mathrm{mg} / \mathrm{L}$ This observation agreed with the observation of Bhuiyan and Gupta(2007) WHO(1984) . This report supports that the pond water can be use for drinking purpose. Total alkalinity and total hardness are within the permissible limit. The Calcium and Magnesium was below the desirable limit of BIS (1994). The iron content in the pond water ranged from $0.11 \mathrm{mg} / \mathrm{L}$ to $4.87 \mathrm{mg} / \mathrm{L}$ and the Nitrite level in the water found to be $.06 \mathrm{mg} / \mathrm{L}$ throughout the study as similarly reported by Ariyadaj et.al., (2005) and Sachindanada moorthy and Yajurvedi (2006).The chloride ,Sulphates and Flouride content was found to be less than the permissible limitof $\mathrm{WHO}(1984)$ supporting the pond water can be used for drinking. .Phosphate content observed very less in the water.The low range of phosphate is due to assimilation by phytoplanktons and microorganisms.(Das 2000, Bhuiyan and Gupta 2007). The content of silica in the water ranged between 5.67mg/L and $12.99 \mathrm{mg} / \mathrm{L}$. .The water quality parameters observed in the pond could be used for drinking and fish culture by adding some basic nutrients and suitable disinfectants.

Murugan (2000) reported that the algal species belonging in four classes namely Cyanophyceae, Chlorophyceae, Bacillariophyceae, Euglenophyceae during their investigation.similiar observation was present with the total of 51 species.

Chlorophyceae of 21 species observed to be dominant over other three algal classes as similarly reported by Murugan(2008)The $\mathrm{pH}$ value play the positive role of the chlorophyceae growth. Chlorocococcoles of 7 species come under chlorophyceae, which is dominant due to high temperature $\left(22-34^{\circ} \mathrm{C}\right)$ and low Nitrate content. Malliswar et.al., (2007).The Cyano[hycean were recorded 14 species, less in number compared to chlorophyceae. Rani et.al.,(2004) was reported that low amount of dissolved oxygen reduces the cyanobacterial population. During the month from November 2009 to July 2010.

12 species of Bacillariophyceaes members were less compared with other classes such as chlorophyceae and Cyanophyceae similar report was given by Murugan (2008). The members of Euglenophyceae were recorded very less with four species during the study period.

The species of Oscillatoria, Scenedesmus, Navicula, Pinnularia of the phytoplankton recorded in the most of the months during the study period as similarly reported by Singh.S.P., et .al., (2002) and Garg et.al., (2010)

\section{Conclusion:-}

The present study concludes that in spite of the fact that phytoplankton are ubiquitous, their population dynamics are often influenced by the available nutrients and physical-chemical conditions of the ecosystem. Thus, fresh water lentic ecosystem of the pond can be a very good source of water for drinking and domestic use and also generating income from fishery. Hence, it is necessary to protect and conserved these water bodies . This demands immediate action from ecologist, planners, and policymakers.

\section{References:-}

1. APHA, (American Public Health Association) 2005. Standard Methods for the Examination of Water and Waste Water. $21^{\text {st }}$ edn, Washington. DC.

2. Adesalu,T.A.and D.L. Nawankaow , 2008, Effect of water quality Index on phytoplankton of a sluggish Tidal Greek in Logos, Nigeria.Pak J.Biol.Sci., 11,836-844. 
3. Akbay.N Amul., Yuti.S., 1999, Seasonal distribution of large phytoplankton in keban dam reservoir, plank. Res., 21(4) 771-787.

4. Ariyadej.C., Tanasakul.R., 2005, Physical-Chemical factors controlling phytoplankton in Bang Lang dam reservoir, yala province. The second national conference on algal and plankton. Chiang mai. 575-578.

5. Ariyadej.C., Tanasakul.R., 2004, Phytoplankton diversity and its relationships to the Physico-Chemical environment in the bangang reservoir, yala province .songklamnarcarlin journal of science and technology, 26.595-607.

6. Bhuiyan.A.K., J.Environ.Bio. 2007, Acomparative hydro biological study of a few ponds of barul valley.Assam and their role as sustainable water resources, 28 799-802.

7. Das.A.K, 2000, Phytoplankton primary in some selected reservoirs of Andhra Pradesh.Geo.Bios, 29.37-44.

8. Garg R.K, Rao.R.J. 2010, Seasonal variations in water quality and major threats to Ramsagar reservoir, India Africans, J.Environ.Sci , Vol.4(2) 61-76.

9. Kamat.S and V.Sime, 2005, Hydrobiological studies of two temple ponds . Ecolo.Environ.Cons., 6 361-367.

10. Kishore.K and Joshi.B.D, 2001, 2005, Physico-Chemical characteristics of pond water of Khangpur village in Bareilly district (U.P) 19.89-91.

11. Krishnamoorthy V, 2002, Algae in India and neighboring Countries chlorophyata oxford I B M pbl, 203.

12. Malliswari.V.D.S. Krupanidhi 2007, Algal biodiversity in a man -made water body. Indian Hydrology, 10(1) 87-97.

13. Murugan,C.B. and Dhande R.R, 2000, Algal biodiversity with respect to pollution status of wadali lake, amaravathi(M.P) India. J.A.Biol.Vol. 15(1) 1-5.

14. Rajagopal.T, Thangamani.A 1, 2010, Comparison of Physico-Chemical parameters and phytoplankton species diversity of two perennial ponds in Sattur area Tamil Nadu. J. Environ.Biology, 31(5) 787-794.

15. Rani.R, Gupta.B.K., and Srivastava.K.B., 2004, Studies on water quality assessment in Patna city (M.P) sessonal parametric variations Nat.Env.Tech., 3(4) 563-565.

16. Sachinandamurthy.K.L. and H.N Yajurvedi, 2006, A study on Physico-Chemical parameters of an aquatic body in Mysore city., Karnataka.,In.J.Env.Biol. 27.615-618.

17. Singh.S.P. Pathak D. and Singh J.R, 2002, Hydrolobiological studies of two ponds of Satha (M.P) In.Eco.Env.Conser, 8.289-292. 